\title{
Variation in the Course and Termination of the Cephalic Vein in the Deltopectoral Triangle
}

\author{
Atoni Atoni Dogood, Oyinbo Charles Aidemise \\ Department of Human Anatomy, Faculty of Basic Medical Sciences,Niger \\ Delta University, Wilberforce Island, Bayelsa State, Nigeria
}

\section{SUMMARY}

The knowledge of cephalic vein variation would aid proper identification and prevent error in surgical emergencies. The path, distribution, and termination of the cephalic vein in relation to the deltopectoral triangle were studied in twenty formalin-embalmed cadavers.

Results show the bilateral presentation of the cephalic vein in all the shoulders examined. Thirtyseven (37) cases presented with a superficial and lateral course of the cephalic vein in the deltopectoral groove, while the rest three cases presented a deep course. Of these 37 cases with the superficial course, two cases ascended anteriorly and above the clavicle and drained into the external jugular vein in the neck. Another case presented a cephalic vein that ascended anteriorly and then above the clavicle and drained into an unnamed vein in the neck. In one case, the cephalic vein ascended superficially in the deltopectoral groove and laterally in the deltopectoral triangle. In one bilateral pattern, the cephalic vein in the deltopectoral triangle drained into the axillary vein. In all the three cases where the cephalic vein ascended deep within the deltopectoral groove, they terminated deep in the deltopectoral triangle. In one of these, the cephalic vein received a tributary that originated from a venous network beneath the deltoid muscle and then drained into athe xillary vein, deep in the deltopectoral triangle. In the other two cases, the cephalic vein gave a tributary to the axillary vein and continued deep and medially in the deltopectoral triangle, passed below the clavicle and drained into the subclavian vein.

The knowledge of these variations of the cephalic vein is essential to clinicians and surgeons for venous access during emergencies and surgery.

Key words: atypical, axillary vein, venous access, deltopectoral groove 


\section{INTRODUCTION}

The cephalic vein originates from the radial end of the dorsal venous network of the hand $(1,2)$, which is a formation of the convergence of dorsal metacarpal veins $(3,4)$. The cephalic vein crosses superficial to the anatomical snuffbox at the base of the thumb and the surface of the radial styloid and runs along the lateral border of the limb. In the forearm, it ascends anterior to brachioradialis and communicates directly with the basilic vein via the median cubital vein before entering the cubital fossa, a situation that occurs in $84 \%$ of cases $(5,6)$. In the arm, it ascends along the lateral border of biceps brachii and crosses to the deltopectoral groove at the proximal third of the arm. Here it lies superficial in the fat pad that spreads transversely between the deltoid and pectoralis major muscles (7). Then it pierces the clavipectoral fascia and drains into the axillary vein at the deltopectoral triangle. Success in pacemaker and defibrillator implantation and central venous access is easily achieved with the cephalic vein (8-10, 19, 20). Khan et al. (11) also described the successful use of the cephalic vein in the carotid patch.

The paucity of detailed anatomical descriptions of the cephalic vein has given credence to reports indicating difficulty locating and recognizing the cephalic vein in the deltopectoral triangle during surgery (12, 13). These difficulties are of critical clinical significance (5). The aim of this study was to document and provide data on the variations of the course, distribution and termination of the cephalic vein in relation to the deltopectoral triangle. Awareness of these variations will help to reduce confusion and complications during surgery.

\section{MATERIAL AND METHODS}

Twenty formalin (10\%) embalmed male cadavers between the ages of 25-35 years old deposited at the Department of Human Anatomy, Faculty of Basic Medical Sciences, College of Health Sciences, Niger Delta University were used for this study. The gross anatomy of the cephalic vein was examined in 40 shoulders (20 right and 20 left) during dissection over a period of three years between 2014-2016.

To expose the cephalic vein and pectoral region skin incision was made from the midline of sternum, extending from the xiphoid process to the jugular notch. These superficial landmarks on the cadaver were noted prior to making the incision. The incisions were extended laterally from the xiphoid process and laterally from the jugular notch along the clavicle to the tip of the acromion of the scapula. An incision was also extended from the tip of the acromion to meet perpendicular with transverse skin incision on the mid$\mathrm{arm}$. The flap of skin was then reflected. Skin incision was also made on the neck and flap of skin reflected to expose the branches and termination of the cephalic vein. In two cases (left shoulders), the pectoralis major muscle was pulled medially to expose the cephalic vein lying deep in the deltopectoral groove and deltopectoral triangle. The usual and unusual patterns of the cephalic vein in the deltopectoral triangle were then documented. Photo-graphs of the dissected shoulders were taken using 8 mega pixels digital camera.

\section{RESULTS}

The cephalic vein was bilaterally present in all the cadavers dissected. The superficial course of the cephalic vein in the deltopectoral groove and deltopectoral triangle was observed in 37 cases. However, three cases presented cephalic vein located deep in the deltopectoral groove and deltopectoral triangle. Our findings show that cephalic vein variation in the deltopectoral triangle occurred in six cases out of the aforementioned 37 cases. In two cases, cephalic vein crossed the proximal $1 / 3$ of the arm, ascended the deltopectoral groove and lied along the lateral part of the deltopectoral triangle superficially. It continued its course anteriorly and above the lateral third of the clavicle and terminated in the neck by draining directly into the external jugular vein (Figures 1 and 4). Figure 2 shows a case where cephalic vein crossed the proxy mal $1 / 3$ of the arm, ascended the deltopectoral groove and along the lateral part of the deltopectoral triangle superficially. It continued its course anteriorly and above the lateral third of the clavicle and terminated in the neck by draining into an unnamed vein with a blind end. The unnamed vein also drained external jugular vein and emptied into the subclavian vein. Figure 3 shows a case where cephalic vein coursed superficially in the deltopectoral groove and along the lateral part of the deltopectoral triangle. It then terminated in the deltopectoral triangle by draining into the axillary vein. Before the cephalic vein drained into the axillary vein, it communicated with external jugular vein via a collateral venous communicantis that ascended anteriorly and above the lateral third of the clavicle. 


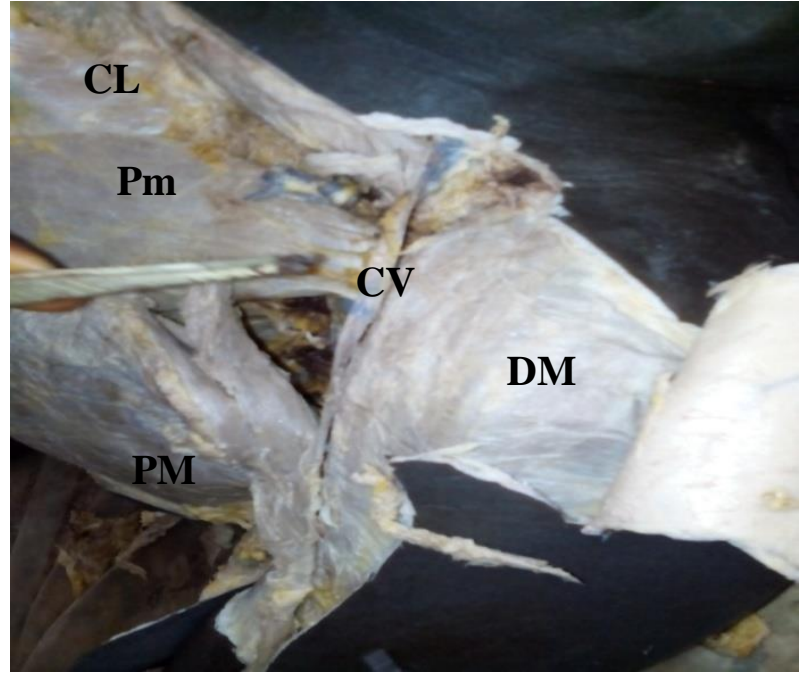

Figure 1. Dissected specimen showing clavicle (CL), deltoid muscle (DM), pectoralis major (PM), pectoralis minor (Pm) and $(\mathrm{CV})$ cephalic vein crossing above the clavicle.

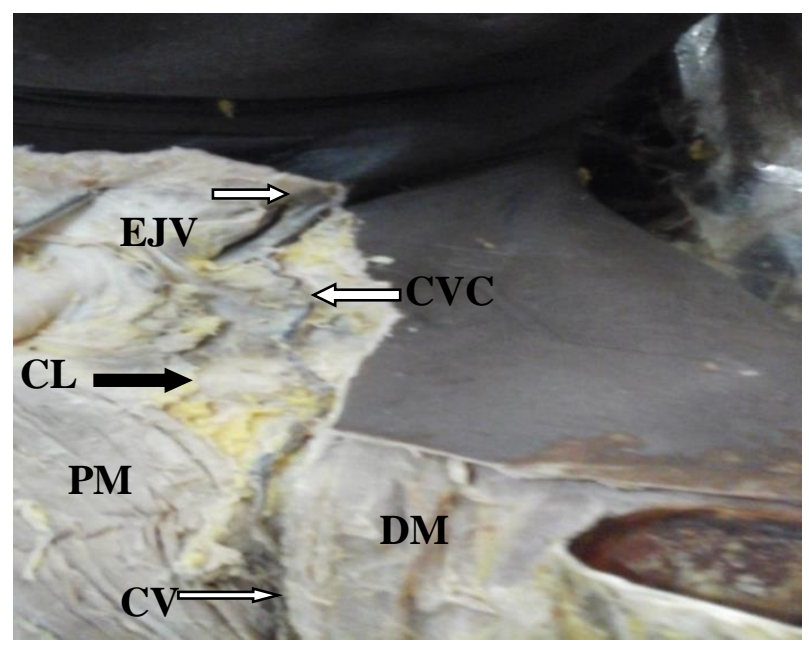

Figure 3. Dissected specimen showing the clavicle (CL), deltoid muscle (DM), pectoralis major (PM), cephalic vein (CV) terminating at the deltopectoral triangle as well as communicating with the external jugular vein (EJV) via a collateral venous communicantes (CVC) (arrow).

Interestingly, a bilateral variation of cephalic vein was found in the right and left shoulders of a particular cadaver. These two cases presented a cephalic vein that ascended superficially in the deltopectoral groove and along the lateral part of the deltopectoral triangle. It then terminated in the deltopectoral triangle by draining into axillary vein. Before terminating, the cephalic vein drained a superficial tributary originating from a venous net-work on the deltoid muscle superficially (Figures 5 and 6).

Among the three cases that presented a deep course

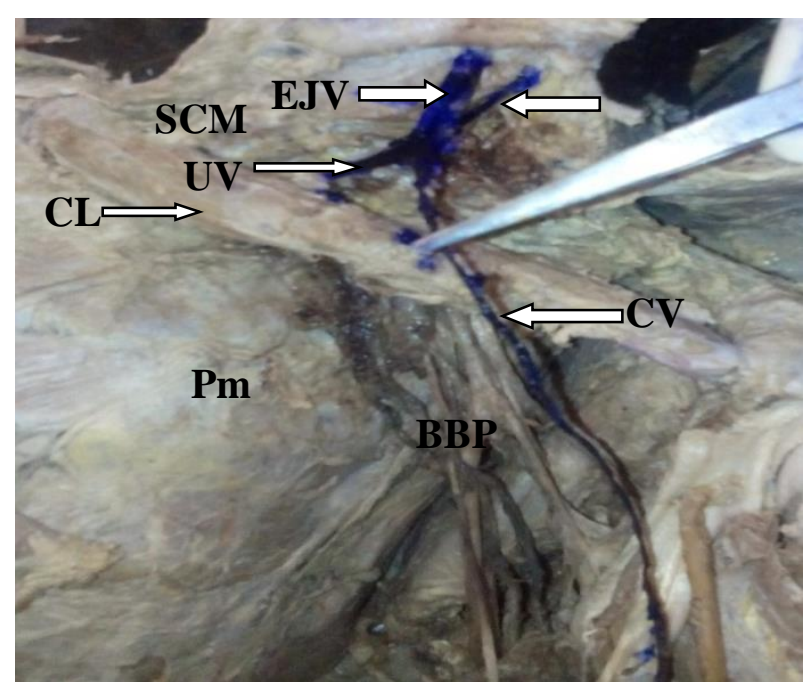

Figure 2. Dissected specimen showing clavicle (CL), pectoralis minor (Pm), sternocleidomastoid (SCM), branches of brachial plexus (BBP), external jugular vein (EJV) receiving a tributary $(\mathrm{T})$, cephalic vein $(\mathrm{CV})$ crossing above the clavicle and terminating in an unnamed vein (UV) that drains the external jugular vein (arrow).

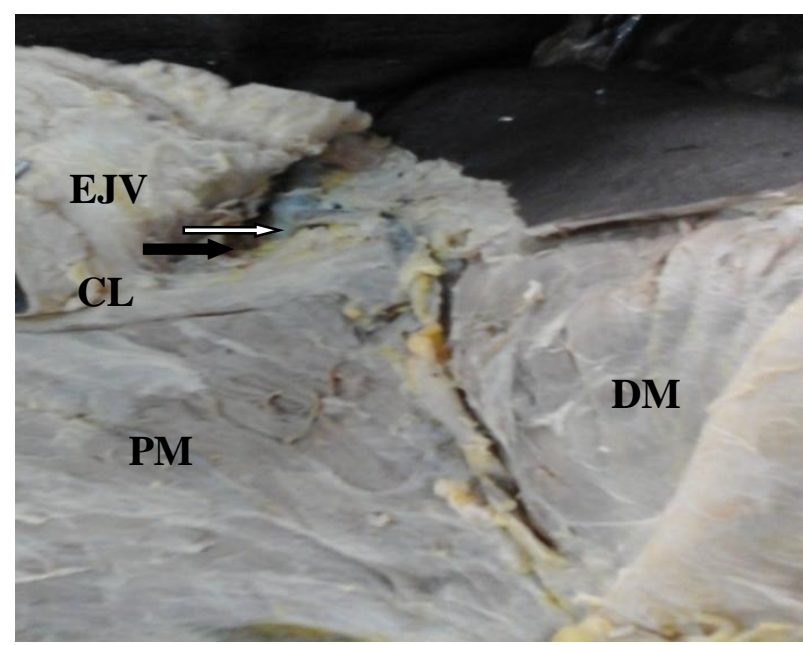

Figure 4. Dissected specimen showing clavicle (CL), deltoid muscle (DM), pectoralis major (PM), cephalic vein $(\mathrm{CV})$ passing the lateral part of deltopectoral triangle and crossing above the clavicle to terminate in the external jugular vein (EJV) (arrow).

and termination of cephalic vein in the deltopectoral triangle, a particular case shows that cephalic vein crossed the proximal $1 / 3$ of the arm superficially and ascended deep in the deltopectoral groove. Here, it drained a deep tributary originating from a network of veins beneath the deltoid muscle. It continued its course and terminated deep in the deltopectoral triangle by draining into axillary vein (Figure 7). The remaining two cases presented cephalic vein that crossed the proximal $1 / 3$ of the arm superficially and ascended deep in the deltopectoral groove. 
Here, the cephalic vein gave a tributary to the axillary vein. It continued deep and medially in the deltopectoral triangle and passed below the clavicle terminating in the subclavian vein (Figure 8).

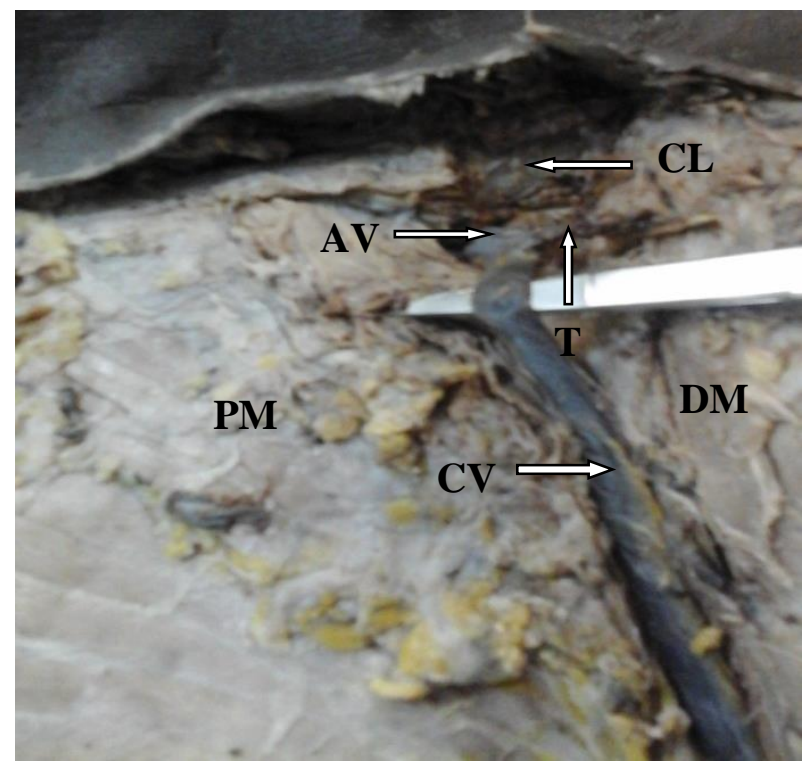

Figure 5. Dissected specimen showing the clavicle (CL), deltoid muscle (DM), pectoralis major (PM) and cephalic vein (CV) erminating in the axillary vein (AV) as well as receiving a tributary (T) that drian the superoanterior and posterior part of the deltoid muscle and the overlying skin (arrow).

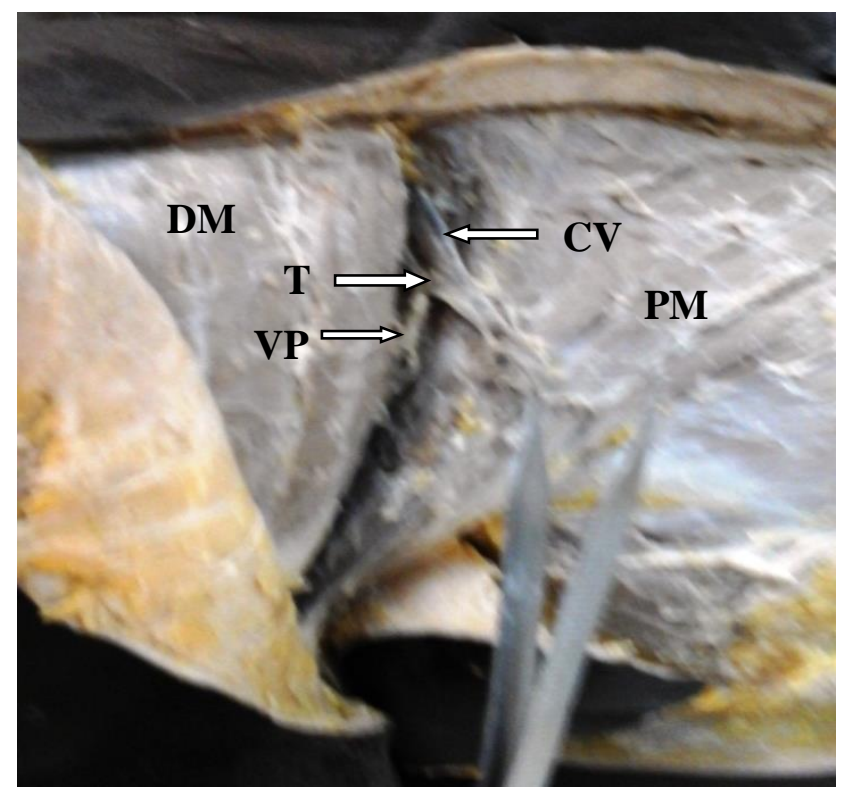

Figure 7. Dissected specimen showing deltoid muscle (DM), pectoralis major $(\mathrm{PM})$ and cephalic vein $(\mathrm{CV})$ receiving a tributary (T) deep in the deltopectoral groove from a venous plexus (VP) before terminating deep at the deltopectoral triangle (arrow).
However, 31 cases presented the normal course and termination of the cephalic vein in the deltopectoral triangle described earlier in this work.

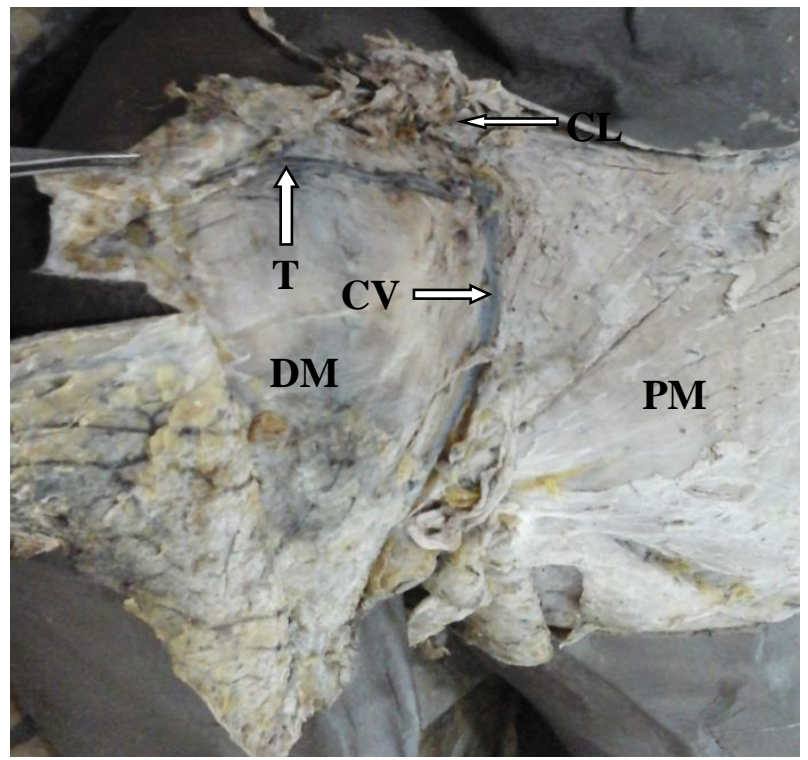

Figure 6. Dissected specimen showing the clavicle (CL), deltoid muscle (DM), pectoralis major (PM) and cephalic vein (CV) erminating and receiving a tributary $(\mathrm{T})$ at the detopectoral triangle (arrow).

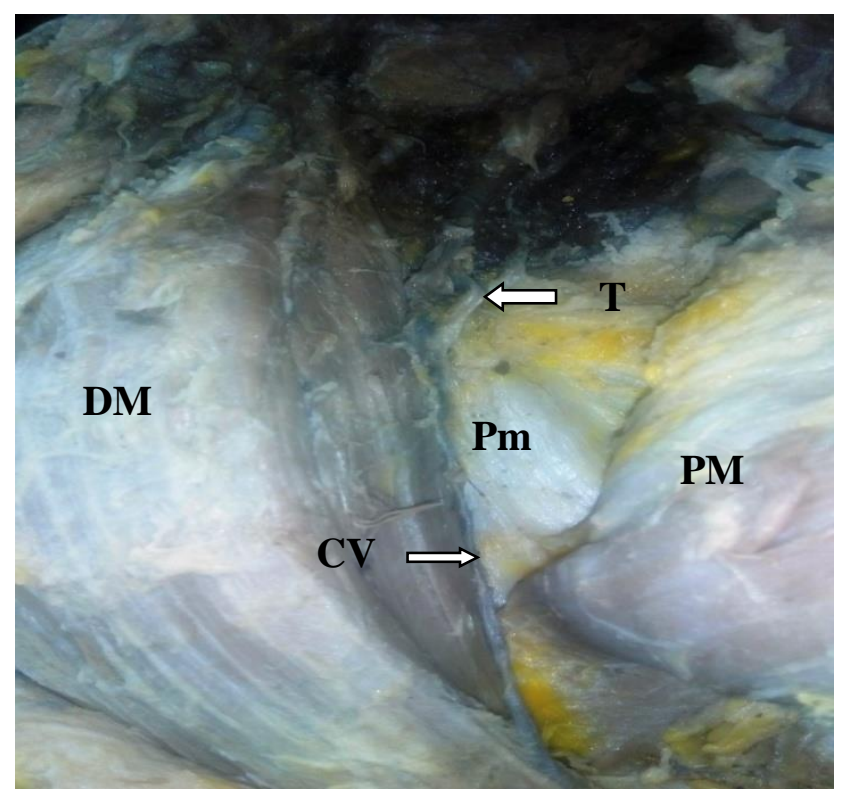

Figure 8. Dissected specimen showing the clavicle (CL), deltoid muscle (DM), reflected pectoralis major (PM), pectoralis minor $(\mathrm{Pm})$, cephalic vein $(\mathrm{CV})$ that lies deep in the deltopectoral groove giving a tributary $(\mathrm{T})$ to axillary vein before passing beneath the clavicle medially to terminate in the subclavian vein (arrow). 


\section{DISCUSSION}

The cephalic vein has become clinically important in view of its significant anatomical variations. This study showed a bilateral presence of cephalic vein in all the cadavers that were dissected. It was mostly found superficial in the deltopectoral groove and along the lateral part of the deltopectoral triangle. Clinicians may try to locate the cephalic vein at the lateral part of the deltopectoral groove and triangle in view of this knowledge (13). Although some cases of absence of cephalic vein has been reported (13-16), studies have shown that the superficial course of the cephalic vein makes it safe for venous access $(13,17)$. This gives credence to our findings that the cephalic vein is superficial in most of its course in the deltopectoral groove and along the lateral part of the deltopectoral triangle.

Our findings have shown the cephalic vein located deep in the deltopectoral groove and triangle in three cases. This agrees with previous study that $20 \%$ of cases showed the cephalic vein located deep in the deltopectoral groove and triangle, which would make venous catheterization difficult (13). This may also pose difficulty identifying the cephalic vein thereby leading to misinterpretation of the presence of cephalic vein, especially during dissections.

An unexpected upward catheter deviation through the external jugular vein may occur during catheterization to access cardiac cavities.
This may occur in view of the cephalic vein termination in the external jugular vein, and the collateral venous communicantes between the cephalic vein and external jugular vein found in our study. Other studies $(4,13,17,15,18)$ have also given support to our findings that cephalic vein may ascend above the clavicle anteriorly and terminate in the neck by draining into the external jugular vein. More so, a collateral venous communicantes may also pass above the clavicle between the cephalic vein and external jugular vein. Although rare, the cephalic vein may also be seen ascending above the clavicle anteriorly and terminating in an unnamed vein in the neck.

This present study reports rare findings in which the cephalic vein courses anteriorly and above the clavicle at the lateral third of the clavicle. Evidence of this variation is scarce in the reference literature. A clinical significance of this variation is that fracture of the clavicle at this point may rupture a cephalic vein and cause an unexpected severe bleeding.

\section{CONCLUSION}

The knowledge of cephalic vein variation in and around the deltopectoral groove and deltopectoral triangle is essentially critical to clinicians and surgeons. This will assist in identifying and locating the cephalic vein while attempting catheterization and cannulation during emergencies and surgery. 


\section{References}

1. Hallock G. The cephalic vein in microsurgery. Microsurgery 1993;14:482-5.

https://doi.org/10.1002/micr.1920140804

2. Hollinshead WH. Anatomy for Surgeons vol.3. $2^{\text {nd }}$ Ed. New York, Harper and Row,1966;p344,357,397.

3. Moore KL, Dalley AF. Clinically Oriented Anatomy $5^{\text {th }}$ Ed. Baltinore, Lippincott Williams and Wilkins, 2006; p.748-9.

4. Standring S. Gray's Anatomy 39th Ed. Edinburgh, Elsevier, Churchill Livingstone, 2005; p.885-7.

5. Au FC. The anatomy of the cephalic vein. Am Surg 1989;55:638-9.

6. Bergman R, Thompson SA, Affi AK. Coompendium of Human Anatomy Variation. Baltimore, Urban and Schwerzenberg, Inc. MD,1988; 431: 90-1.

7. Clemente CD. Gray's Anatomy $30^{\text {th }}$ American Ed. Philadelphia, The veins, Lea and Febiger, 1985; p. 820-1.

8. Chen JY, Chang KC, Lin YC, Chou HT, Hung JS. Feasibility and accuracy of preprocedure imaging of the proximal cephalic vein by duplex ultrasonography in pacemaker and defibrillator implantation. J Interv Card Electrophysiol 2004; 10:31-5.

https://doi.org/10.1023/B:]ICE.0000011482.58569.74

9. Neri R, Cesario AS, Baragli D, Monti F, Danisi N, Glaciale G, Gambelli G. Permanent pacing lead insertion through the cephalic vein using an hydrophilic guide wire. Pacing Clin. Electrophysiol 2003;26:2313-4. https://doi.org/10.1111/j.1540-8159.2003.00365.x

10. Povoski SP. A prospective analysis of the cephalic vein cut-down approach for chronic indwelling central venous access in 100 consecutive cancer patients. Am Surg Oncol 2000;7(7):496-502. https://doi.org/10.1007/s10434-000-0496-9

11. Langard R, Vogt OE, Hono A.I, Arteger C.R. La vena cephálica, sos modos de terminción y variedadesen el surco delto-pectoral. XXIIC Congresso Argentino de anatomía, UNLP, 1985.

12. Nobili O.I. Actualización de la investigación de la vena cefálica en el surco delto-pctoral. La samena Médica, A-o LXXXIII, 1976;149(16):536-7.

13. Khan RSA, Simms M. Cephalic vein for carotid patching. EJVES Extra, 2005;9:35-6.

https://doi.org/10.1016/j.ejvsextra.2005.01.011

14. Chen J, Chang KC, Lin YC, Hung JS. Pre-procedure duplex ultrasonography to assist cephalic vein isolation in pacemaker and lead defibrillator implantation. J Interv Card Electrophysiol 2005;12(1):7581.

\section{https://doi.org/10.1007/s10840-005-5844-z}

15. Loukas M, Myers CS, Wartmann ChT, Tubbs RS, Judge T, Curry T, Curry B, Jordan R. The clinical anatomy of the cephalic vein in the deltopectoral triangle. Folia Morphol (Warsz) 2008;67(1):72-7.

16. De Rosa F, Talarico A, Mancuso P, Plastina F. New introducer technique for implanting pace makers and defibrillator leads: Percutaneous incannulation of the cephalic vein. G Ital Cardiol 1998;28(10):1094-8.

17. Le Saout J, Vallee B, Person H, Doutriaux M, Blanc J, Nguyen H. Anatomical basis for the surgical use of the ceohalic vein. 74 anatomical dissections. 189 surgical dissections. J Chir (Paris) 1983;120:(2) :131-4.

18. Reid CD, Taylor GI. The vascular territory of the acromioclavicular axis. Br J Plast Surg 1984;37:194212. https://doi.org/10.1016/0007-1226(84)90010-9

19. Yeri LA, Houghton EJ, Palmien B, Flores M, Gomez JE. Cephalic vein. Detail of the anatomy in the deltopectoral triangle. Int J Morphpol 2009;27(4):1037-42.

20. Poirier P, Charpy A. Traite $\mathrm{d}$ anatomie humanie. Masson et Cie 2, Pris 1909. 


\title{
Varijacije u toku i završetku cefalične vene u deltopektoralnom trouglu
}

\author{
Atoni Atoni Dogood, Oyinbo Charles Aidemise \\ Departman za humanu anatomiju , Fakultet osnovnih medicinskih nauka, Nigerija \\ Univerzitet Delta, Ostrvo Wilberforce, Država Bayelsa, Nigerija
}

\section{SAŽETAK}

Poznavanje varijacija cefalične vene omogućilo bi njenu adekvatnu identifikaciju i sprečilo pravljenje grešaka u hitnim hirurškim intervencijama. Put, grananje i završetak cefalične vene u odnosu na deltopektoralni trougao analizirani su kod dvadeset kadavera potopljenih u formalin. Rezultati ukazuju na bilateralnu prezentaciju cefalične vene kod svih analiziranih ramena, Kod 37 slučajeva zabeležen je površinski i lateralni tok cegalične vene $\mathrm{u}$ deltopektoralnom trouglu, dok je u preostala tri slučaja zabeležen duboki tok. Od 37 slučajeva s površinskim tokom, $u$ dva slučaja vena se spustila anteriorno i iznad klavikule $i$ ulila $u$ spoljašnju jugularnu venu vrata. $U$ drugom slučaju, vena se spustila anteriorno, potom se kretala iznad klavikule i ulila u bezimenu venu u vratu. $U$ jednom od slučajeva, cefalična vena se kretala uzlazno površi-nskim tokom i lateralno $\mathbf{u}$ deltopektpralnom trouglu. $\mathrm{U}$ bilateralnomobrascu, cefalična vena se $\mathbf{u}$ deltope-ktoralnom trouglu ulila u aksilarnu venu. $U$ sva tri slučaja gde je cefalična vena ušla duboko $u$ deltope-ktoralni trougao, tu se i završila. $U$ jednom od ovih slučajeva, cefalična vena je imala pritoku koja je krenula iz mreže vena ispod deltoidnog mišića, a potom se ulila u aksilarnu venu duboko $u$ deltopektoralnom trouglu. $U$ preostala dva slučaja iz cefalične vene je krenula pritoka do aksilarne vene, koja je nastavila dubokim tokom i medijalno kroz deltopektoralni trougao, ispod klavikule i ulila se u subklavikularnu venu. Poznavanje ovih varijacija cefalične vene je od suštinskog značaja za kliničare i hirurge zbog pristupa ovoj veni u toku hirurških i hitnih interventnih stanja.

Ključne reči: atipična, aksilarna vena, pristup veni, deltopektoralni trougao 
Original article 